\title{
Haloarcula argentinensis sp. nov. and Haloarcula mukohataei sp. nov., Two New Extremely Halophilic Archaea Collected in Argentina
}

\author{
KUNIO IHARA, ${ }^{*}$ SATOSHI WATANABE, AND TAKESHI TAMURA \\ Division of Biological Science, Graduate School of Science, Nagoya University, Nagoya 464-01 Japan
}

\begin{abstract}
Strains $\arg -1^{T}\left(T=\right.$ type strain) and $\arg -2^{T}$, two new strains of extremely halophilic archaea, were isolated from the soils of the Argentine salt flats. The taxonomic features of arg- $1^{\mathrm{T}}$ were similar to, but distinct from, those of the type strain of Haloarcula vallismortis and other Haloarcula species. On the 16S rRNA phylogenetic tree, strain $\arg -1^{\mathrm{T}}$ formed a cluster together with Haloarcula species. Strain $\arg -2^{\mathrm{T}}$ differed in its glycolipid composition but still was more closely related to the genus Haloarcula than to other established genera. We propose that strain $\arg -1^{\mathrm{T}}$ be classified as a member of a new species, Haloarcula argentinensis, and that strain $\arg -2^{\mathrm{T}}$ be classified as a member of Haloarcula mukohataei $\mathrm{sp}$. nov., although $\arg -2^{\mathrm{T}}$ may belong to a new genus or a subgenus of the genus Haloarcula. The type strain of $H$. argentinensis is strain arg-1 (= JCM 9737), and the type strain of $H$. mukohataei is strain arg-2 (= JCM 9738).
\end{abstract}

Extremely halophilic archaea have been isolated from various hypersaline environments and have been classified into four nonalkaliphilic genera and two alkaliphilic genera on the basis of phenotypic and genetic criteria (4). Recent phylogenetic analysis of 16S rRNA genes revealed a great degree of taxonomic diversity at the genus level within the family Halobacteriaceae $(9,17)$. Seven genera of nonalkaliphilic halobacteria have been described (the genera Halobacterium, Halococcus, Haloarcula, Haloferax, Halorubrum [Halorubrobacterium], Halobaculum, and Natrialba), and two genera of alkaliphilic halobacteria have been described (the genera Natronobacterium and Natronococcus) $(9,17,21)$.

Strains $\arg -1^{\mathrm{T}}(\mathrm{T}=$ type strain $)$ and $\arg -2^{\mathrm{T}}$, two new halophiles collected in Argentina, were found to possess the lightdriven proton pump retinal proteins cruxrhodopsin-1 and cruxrhodopsin-2, respectively $(28,29)$. The results of phylogenetic analyses performed with bacteriorhodopsin homologs suggested that the halobacterial strains containing members of the cruxrhodopsin family are distributed in one genus, the genus Haloarcula (19), and the light-driven ion pump of the cruxrhodopsin family was identified in the type species of this genus, Haloarcula vallismortis (13). We propose that the two new isolates from Argentina should be classified in the genus Haloarcula on the basis of the results of a 16S rRNA phylogenetic analysis and a DNA-DNA hybridization analysis.

\section{MATERIALS AND METHODS}

Strains and culture conditions. Strain $\arg -1^{\mathrm{T}}$ was collected in Salinas Chica on the Valdez Peninsula in Chubut, Argentina, and strain arg- $2^{T}$ was collected in Salinas Grandes in the Andes highlands in Jujuy, Argentina. Reference strains, including Haloarcula vallismortis IFO $14741^{\mathrm{T}}$ (= ATCC $29715^{\mathrm{T}}$ ), Halobacterium saccharovorum IFO $14717^{\mathrm{T}}\left(=\right.$ DSM $1137^{\mathrm{T}}$ ), Halobacterium cutirubrum IFO $14715^{\mathrm{T}}$ (= DSM $\left.669^{\mathrm{T}}\right)$, Halobacterium sodomense IFO $14740^{\mathrm{T}}$ (= ATCC $\left.33755^{\mathrm{T}}\right)$, Haloferax volcanii $\mathrm{IFO} 14742^{\mathrm{T}}\left(=\mathrm{ATCC} 29605^{\mathrm{T}}\right)$, and Haloferax mediterranei IFO $14739^{\mathrm{T}}$ ( = ATCC $33500^{\mathrm{T}}$ ), were purchased from the Institute for Fermentation, Osaka, Japan. Haloarcula marismortui JCM $8966^{\mathrm{T}}$ (= ATCC $\left.43049^{\mathrm{T}}\right)$, Haloarcula japonica JCM $7785^{\mathrm{T}}\left(=\mathrm{T}\right.$. Takashina TR-1 $\left.{ }^{\mathrm{T}}\right)$, Haloarcula hispanica JCM 8911" (= IAM 13179), and "Haloarcula sinaiiensis" JCM 8862 were purchased from the Japan Collection of Microorganisms, Institute of Physical and Chemical Research (RIKEN), Saitama, Japan. Halobacterium cutinbrum has been transferred to Halobacterium salinarum (34). Halobacterium saccharovorum and Halobacterium sodomense have been transferred to the new genus Halorubrum and renamed Halorubrum saccharovorum and Halorubrum sodomense, respectively (17). (Another new genus, the genus Halorubrobacte-

\footnotetext{
* Corresponding author. Fax: 81-52-789-2968. E-mail: Kihara@bio .nagoya-u.ac.jp.
}

rium, has also been proposed for strains of Halobacterium saccharovorum and Halobacterium sodomense [9].) The new names are used in this paper.

The basal culture (BC) medium contained (per liter of tap water) $156 \mathrm{~g}$ of $\mathrm{NaCl}, 4 \mathrm{~g}$ of KCl, $20 \mathrm{~g}$ of $\mathrm{MgSO}_{4} \cdot 7 \mathrm{H}_{2} \mathrm{O}, 13 \mathrm{~g}$ of $\mathrm{MgCl}_{2} \cdot 6 \mathrm{H}_{2} \mathrm{O}, 1 \mathrm{~g}$ of $\mathrm{CaCl}_{2}$. $2 \mathrm{H}_{2} \mathrm{O}, 0.2 \mathrm{~g}$ of $\mathrm{NaHCO}_{3}$, and $0.5 \mathrm{~g}$ of $\mathrm{KBr}(\mathrm{pH} 7.5)$, as described elsewhere (22). Liquid medium was solidified by adding $1.6 \%$ agar before autoclaving. Carbohydrate utilization tests were performed with $\mathrm{BC}$ medium containing $0.1 \mathrm{~g}$ of yeast extract per liter and each sugar at a concentration of $0.1 \%$. Acidification of the culture medium was monitored with a $\mathrm{pH}$ meter.

For the following tests, $\mathrm{BC}$ medium was enriched with $5 \mathrm{~g}$ of yeast extract per liter and $1 \mathrm{~g}$ of D-glucose per liter. The growth response to salt was examined by using $\mathrm{NaCl}$ concentrations ranging from 60 to $260 \mathrm{~g} /$ liter. The $\mathrm{MgCl}_{2} \cdot 6 \mathrm{H}_{2} \mathrm{O}$ requirement was examined by using $\mathrm{MgCl}_{2} \cdot 6 \mathrm{H}_{2} \mathrm{O}$ concentrations ranging from 0 to $75 \mathrm{~g} /$ liter.

Cell growth was monitored by determining the turbidity at $660 \mathrm{~nm}$. Cell motility and cell shape were examined by optical microscopy (Olympus model $\mathrm{BH}-2$ microscope; magnification, $\times 1,000$ ) without fixation or after acetic acid fixation (2).

Biochemical tests. Antibiotic resistance was tested in the enriched culture medium (liquid medium and solid medium) in which the concentrations of $\mathrm{NaCl}$ and $\mathrm{MgCl}_{2} \cdot 6 \mathrm{H}_{2} \mathrm{O}$ were 200 and $20 \mathrm{~g} /$ liter, respectively. Susceptibility was determined by examining the production of visible colonies in solid medium containing each antibiotic. The class of fructose-bisphosphate aldolase was determined by the method of Dhar and Altekar (1). dam methylation of genomic DNA was tested with restriction enzymes $M b o l$ and Sau3AI (15). Other bacteriological tests were carried out as described by Smibert and Krieg (27).

Lipid analysis. Lipids were extracted by the method of Kates and Kushwaha (12), dissolved in chloroform-methanol (1:2, vol/vol), and chromatographed on silica gel thin-layer plates (Kieselgel $60 \mathrm{~F}_{254}$; Merck) by performing two-dimensional thin-layer chromatography (TLC), as described by Minnikin et al. (18). The glycolipids on the plates were visualized as dark blue spots following a short pyrolysis at $150^{\circ} \mathrm{C}$ after the plates were sprayed with $0.5 \% \alpha$-naphthol in methanol-water (1:1) and sulfuric acid-ethanol (1:1). All other lipids were visualized as yellow-brown spots after further pyrolysis at about $250^{\circ} \mathrm{C}$. The $R_{f}$ values were compared with the $R_{f}$ values of authentic standards (33) from the type strains of halobacteria. Chain lengths of core lipids were analyzed by the thin-layer chromatographic procedure described by Ross et al. (23).

DNA base composition and DNA-DNA reassociation. DNA was isolated and purified as described previously (7). The $\mathrm{G}+\mathrm{C}$ content was determined by the thermal denaturation method. DNA-DNA reassociation studies were carried out as described by Tindall et al. (32), with minor modifications; DNA fragments were labeled with $\left[\alpha{ }^{32} \mathrm{P}\right] \mathrm{dCTP}$ by using the random priming method.

16S rDNA amplification and sequencing. Two sets of primers were designed on the basis of the highly conserved regions of halobacterial 16S ribosomal DNA (rDNA) sequences. One set (primer f1 [5'ATTCCGGTTGATCCTGC3'] and primer $\mathrm{r} 1$ [5'TTTAAGTTTCATCCTTG]) was designed for PCR amplification of the region corresponding to positions 1 to 859 (Halobacterium halobium 16S rDNA numbering). The another set (primer $\mathrm{f} 2$ [5'AACCGGATTAGATACCC $\left.3^{\prime}\right]$ and primer $\mathrm{r} 2$ [5'GTGATCCAGCCGCAGATTCC $\left.3^{\prime}\right]$ ) was designed for the region from position 723 to position 1472 (16). The PCR was performed by a routine method (24) for 30 cycles, each of which consisted of denaturation for $30 \mathrm{~s}$ at $96^{\circ} \mathrm{C}$, annealing for $30 \mathrm{~s}$ at $37^{\circ} \mathrm{C}$, and polymerization for $3 \mathrm{~min}$ at $72^{\circ} \mathrm{C}$. The products were separated by electrophoresis, cloned into pUC18 in Escherichia coli, and sequenced by the dideoxy chain termination method (26).

Phylogenetic analysis on the basis of 16S rRNA sequences. Sequence data for halobacterial 16S rRNAs were obtained from DNA Data Bank of Japan 
(DDBJ). The sequences were aligned by using CLUSTAL W (30), and phylogenetic trees were constructed by the neighbor-joining (25) or unweighted pair group with mathematical average method. Arithmetic calculations were performed by using the ODEN system (molecular evolution analysis system) of DDBJ (National Institute of Genetics). The confidence levels for branching orders were evaluated by the bootstrap method (3)

Nucleotide sequence accession numbers. The 16S rDNA sequences of Haloarcula sp. strain arg- $1^{\mathrm{T}}$ (Haloarcula argentinensis), Haloarcula sp. strain arg- $2^{\mathrm{T}}$ (Haloarcula mukohataei), and Haloarcula vallismortis IFO $14741^{\mathrm{T}}$ have been deposited in the DDBJ under accession numbers D50849, D50850, and D50851, respectively.

\section{RESULTS}

Growth conditions and other features. At $40^{\circ} \mathrm{C}$, strain arg- $1^{\mathrm{T}}$ grew optimally in the presence of $2.5 \mathrm{M} \mathrm{NaCl}$, whereas strain $\arg -2^{\mathrm{T}}$ grew optimally in the presence of 3.0 to $3.5 \mathrm{M} \mathrm{NaCl}$. No growth was detected at $\mathrm{NaCl}$ concentrations below $1.5 \mathrm{M}$ for $\arg -1^{\mathrm{T}}$ or below $2.0 \mathrm{M}$ for $\arg -2^{\mathrm{T}}$. Strain $\arg -1^{\mathrm{T}}$ grew well in the presence of $4.5 \mathrm{M} \mathrm{NaCl}$, but the growth of strain $\arg -2^{\mathrm{T}}$ in the presence of $4.5 \mathrm{M} \mathrm{NaCl}$ was rather poor (the growth yield was one-third the growth yield obtained under optimum growth conditions). At the optimum $\mathrm{NaCl}$ concentration for each strain, $\arg -1^{\mathrm{T}}$ grew optimally in the presence of $100 \mathrm{mM} \mathrm{Mg}{ }^{2+}$ and arg- $2^{\mathrm{T}}$ exhibited almost constant growth at $\mathrm{Mg}^{2+}$ concentrations from 3 to $300 \mathrm{mM}$. The minimum $\mathrm{Mg}^{2+}$ concentrations for growth were 30 and $3 \mathrm{mM}$ for $\arg -1^{\mathrm{T}}$ and $\arg -2^{\mathrm{T}}$, respectively. In actively growing liquid cultures, the cells of strain arg- $1^{\mathrm{T}}$ were mostly triangular disks and the cells of strain $\arg -2^{\mathrm{T}}$ were short rods, as determined by phase-contrast microscopic observations. On agar plates, both strains formed orange colonies about $2 \mathrm{~mm}$ in diameter after 1 week of culture. After prolonged culture, both strains sometimes produced a glutinous extracellular material like the polyhydroxybutyrate produced by Haloferax mediterranei. Both strains had flagella and were motile as determined by microscopic observations. Both strains were susceptible (growth was completely inhibited) to novobiocin $(5 \mu \mathrm{g} / \mathrm{ml})$, pravastatin $(10 \mu \mathrm{g} / \mathrm{ml})$, and anisomycin $(10 \mu \mathrm{g} / \mathrm{ml})$ and resistant to penicillin $(10 \mathrm{IU} / \mathrm{ml})$, kanamycin $(30 \mu \mathrm{g} / \mathrm{ml})$, and chloramphenicol $(30 \mu \mathrm{g} / \mathrm{ml})$. Both strains were catalase and oxidase positive and were able to use various kinds of sugars (sucrose, maltose, glucose, galactose, mannose, ribose, and glycerol) and to acidify the medium. Strain $\arg -1^{\mathbf{T}}$ growth was stimulated by fructose, and neither strain utilized lactose. Fructose-bisphosphate aldolase was not inhibited by EDTA in both strains, which is characteristic of a class I enzyme (1). The genomic DNAs of both strains were hydrolyzed by both $\mathrm{MboI}$ and Sau3AI, which suggested that adenosines in the GATC sequences in the genomes were not methylated.

Lipid analyses. Both strain arg- $1^{\mathrm{T}}$ and strain $\arg -2^{\mathrm{T}}$ had $\mathrm{C}_{20}$, $\mathrm{C}_{20}$ diether core lipids, as deduced from a TLC analysis of whole-organism methanolysates (data not shown). The phospholipids of both strains were phosphatidylglycerophosphate, phosphatidylglycerol, and phosphatidylglycerosulfate. Strain arg- $1^{\mathrm{T}}$ contained 1-O-[ $\beta$-D-glucose- $\left(1^{\prime} \rightarrow 6^{\prime}\right)-\alpha-\mathrm{D}-\mathrm{mannose}-$ $\left(1^{\prime} \rightarrow 2^{\prime}\right)$ - $\alpha$-D-glucose]-2,3-di- $O$-phytanyl-sn-glycerol (TGD-2) and an unknown diglycosyl glycolipid (DGD-2), like Haloarcula marismortui (Fig. 1). These two glycolipids were detected in other Haloarcula strains, including Haloarcula vallismortis, Haloarcula hispanica, and Haloarcula japonica strains (data not shown). Strain arg- $2^{\mathrm{T}}$ contained two unknown glycolipids $\left(\mathrm{X}_{1}\right.$ and $\mathrm{X}_{2}$ ), which migrated to positions similar to the positions of 1- $O$ - $\left[\alpha\right.$-D-mannose- $\left(1^{\prime} \rightarrow 2^{\prime}\right)-\alpha$-D-glucose-2,3-di- $O$-phytanyl-snglycerol] (DGD 1) and 1- $O-\left[\alpha-\mathrm{D}-\mathrm{mannose}-\left(6^{\prime}-\mathrm{SO}_{4}^{-}\right)-\left(1^{\prime} \rightarrow 2^{\prime}\right)\right.$ $\alpha$-D-glucose-2,3-di- $O$-phytanyl-sn-glycerol] (S-DGD), respectively (Fig. 1). Cochromatography of lipids from $\arg -2^{\mathrm{T}}$ and Haloferax volcanii produced two rather broad spots in the po-
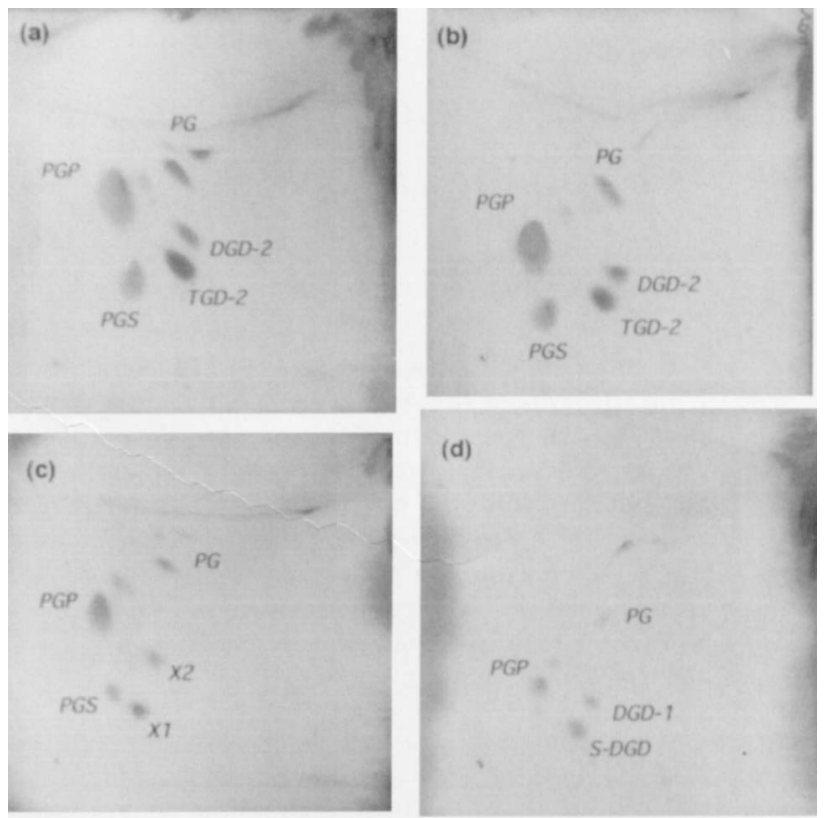

FIG. 1. Polar lipid patterns of strains obtained by two-dimensional TLC on a silica gel plate (Kieselgel $60 \mathrm{~F}_{254}$ ). The solvent systems were as follows: first dimension (from right to left), chloroform-methanol-water $(65: 25: 4, \mathrm{vol} / \mathrm{vol})$; second dimension (from bottom to top), chloroform-methanol-acetic acid-water (80:12:15:4, vol/vol). (a) Strain arg- $1^{\mathrm{T}}\left(=\mathrm{JCM} 9737^{\mathrm{T}}\right)$. (b) Haloarcula marismor tui $\mathrm{JCM} 8966^{\mathrm{T}}$. (c) Strain arg- $2^{\mathrm{T}}$ (= JCM $9738^{\mathrm{T}}$ ). (d) Haloferax volcanii $\mathrm{IFO}$ $14742^{\mathrm{T}}$. PG, phosphatidylglycerol; PGP, phosphatidylglycerophosphate; PGS, phosphatidylglycerosulfate; DGD-2, unknown diglycosyl diether; X1 and X2, unknown glycolipids.

sitions of glycolipids, but cochromatography of lipids from arg- $2^{\mathrm{T}}$ and Haloarcula marismortui produced four distinct glycolipid spots (data not shown).

16S rDNA and phylogenetic analysis. PCR amplification of the $16 \mathrm{~S}$ rDNAs of strains $\arg -1^{\mathrm{T}}$ and $\arg -2^{\mathrm{T}}$ and Haloarcula vallismortis with two sets of primers produced an 859-base fragment from the $5^{\prime}$ end of the 16S rDNA and a 750-base fragment from the $3^{\prime}$ end, which overlapped by 137 bases. As two overlapping sequences, which included one of the most variable regions of the $16 \mathrm{~S}$ rRNA gene, were identical for each fragment pair for the three strains, each pair was considered amplified from one 16S rRNA gene, although the results of Southern analysis suggested that at least four and three genes were present in $\arg -1^{\mathrm{T}}$ and $\arg -2^{\mathrm{T}}$, respectively. The overall sizes of the 16S rDNAs of strains arg- $1^{\mathrm{T}}$ and $\arg -2^{\mathrm{T}}$ and Haloarcula vallismortis were $1,472,1,474$, and $1,472 \mathrm{bp}$, respectively.

A halobacterial phylogenetic tree was constructed by the neighbor-joining method on the basis of the 16S rRNA nucleotide sequences (Fig. 2). Strain arg- $1^{\mathrm{T}}$ was included in the Haloarcula cluster. Although arg $-2^{\mathrm{T}}$ was not closely related to the other members of the genus Haloarcula, it was still closer to the genus Haloarcula than to any other genus. A bootstrap confidence value of $99 \%$ was obtained when strain $\arg -2^{\mathrm{T}}$ was placed on the Haloarcula branch.

DNA-DNA reassociations. The DNA-DNA hybridization values obtained for the species of each genus of non-alkaliphilic halobacteria and strains $\arg -1^{\mathrm{T}}$ and $\arg -2^{\mathrm{T}}$ showed that strains arg- $1^{\mathrm{T}}$ and $\arg -2^{\mathrm{T}}$ were members of the genus Haloarcula (Table 1). Closer investigation with members of the genus Haloarcula showed that arg- $2^{\mathrm{T}}$ was different from previously described Haloarcula species, while arg- $1^{\mathrm{T}}$ was very closely related to Haloarcula hispanica or Haloarcula marismortui. How- 


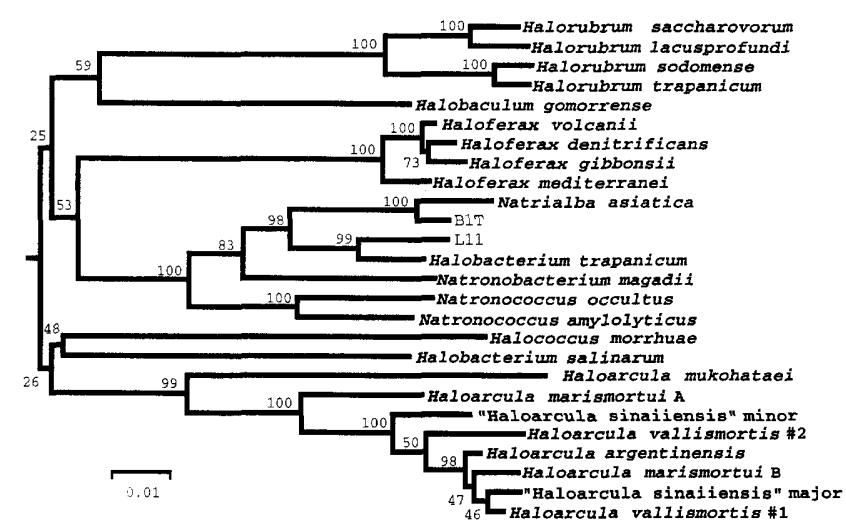

FIG. 2. Phylogenetic tree for the extremely halophilic archaea constructed by the neighbor-joining method. The sequence data used were data for the following strains and were obtained from the DDBJ (accession numbers are given in parentheses): Halorubrum saccharovonum NCIMB $2081^{\mathrm{T}}$ (X82167), Halorubrum lacusprofundi ACAM34 ${ }^{\mathrm{T}}$ (X82170), Halorubrum sodomense ATCC $33755^{\mathrm{T}}$ (X82169), Halorubrum trapanicum NRC $34021^{\mathrm{T}}$ (X82168), Halobaculum gomor rense DSM $9297^{\mathrm{T}}$ (L37444), Haloferax volcanii ATCC $29605^{\mathrm{T}}$ (K00421), Halo ferax denitrificans ATCC $35960^{\mathrm{T}}$ (D14128), Haloferax gibbonsii ATCC $33959^{\mathrm{T}}$ (D13378), Haloferax mediterranei ATCC $33500^{\mathrm{T}}$ (D11107), Natrialba asiatica JCM 9576 (D14124), B1T (= JCM 9577) (D14124), L-11 (D14126), Halobacterium trapanicum NCIMB $767^{\mathrm{T}}$ (D14125), Natronobacterium magadii NCIMB $2190^{\mathrm{T}}$ (X72495), Natronococcus occultus NCIMB $2192^{\mathrm{T}}$ (Z28378), Natronococcus amylotyticus Ah-36 ${ }^{\mathrm{T}}$ (D43628), Halococcus morrhuae ATCC $17082^{\mathrm{T}}$ (X00662), Halobacterium salinarum (Halobacterium halobium) DSM 671 (M38280), Halo arcula mukohataei JCM $9738^{\mathrm{T}}$ (D50850), Haloarcula marismortui A ATCC $34049^{\mathrm{T}}$ (X61688), "Haloarcula sinaiiensis" minor ATCC 33800 (D14130), Haloarcula vallismortis \#2 IFO $14741^{\mathrm{T}}$ (D50851), Haloarcula argentinensis JCM $9737^{\mathrm{T}}$ (D50849), Haloarcula marismortui B ATCC $34049^{\mathrm{T}}$ (X61689), "Haloarcula sinai iensis" major ATCC 33800 (D14129), and Haloarcula vallismortis \#1 ATCC $29715^{\mathrm{T}}$ (U17593) $(5,6,9,11,14,16,17,20)$. Bootstrap percentages are indicated at the nodes. The tree was rooted by using the $16 \mathrm{~S}$ rDNA sequence of Meth anosarcina thermophila DSM 1825 (accession number M59140) as the outgroup.

ever, a DNA-DNA hybridization value of around $60 \%$ is the recommended cutoff point for delineating species (8), and thus $\arg -1^{\mathrm{T}}$ was identified as a member of a species independent from previously described Haloarcula species.

\section{DISCUSSION}

Newly isolated strains $\arg -1^{\mathrm{T}}$ and $\arg -2^{\mathrm{T}}$ were classified as extremely halophilic aerobic archaea because (i) TLC of whole-organism methanolysates revealed that they contain ether-linked isoprenoid lipids, (ii) they could grow in the presence of antibiotics effective against eubacteria (penicillin, kanamycin, and chloramphenicol) but not in the presence of antibiotics effective against eukaryotes (pravastatin and anisomycin), (iii) they could grow aerobically only in the presence of high concentration of $\mathrm{NaCl}$ and lysed at low levels of salinity, and (iv) they possessed bacterial rhodopsins $(28,29)$ which have been found only in members of the order Halobacteriales (4).

Glycolipid analysis is one of the most commonly used conventional methods for determining the genus of bacterial isolates (33). Members of the genus Halobacterium contain 1- $O$ - $\left[\beta\right.$-D-galactose- $\left(3^{\prime}-\mathrm{SO}_{4}{ }^{-}\right)-\left(1^{\prime} \rightarrow 6^{\prime}\right)-\alpha-\mathrm{D}-$ mannose- $\left(1^{\prime} \rightarrow\right.$ $\left.2^{\prime}\right)$ - $\alpha$-D-glucose $]-2,3-\mathrm{di}-O$-phytanyl-sn-glycerol and $1-O-[\beta-\mathrm{D}-$ galactose- $\left(3^{\prime}-\mathrm{SO}_{4}{ }^{-}\right)-\left(1^{\prime} \rightarrow 6^{\prime}\right)-\alpha-\mathrm{D}-\mathrm{mannose}-\left(3^{\prime} \leftarrow 1^{\prime}\right)-\alpha-\mathrm{D}-\mathrm{ga}-$ actofuranose- $\left(1^{\prime} \rightarrow 2^{\prime}\right)-\alpha-\mathrm{D}$-glucose]-2,3-di- $O$-phytanyl$s n$-glycerol as their major glycolipids, members of the genus Haloferax contain S-DGD, and members of Haloarcula contain a triglycosyl diether (TGD-2). Members of the genus Halorubrum contain glycolipids that differ slightly in each case analyzed, although they are still based on a glycosyl-mannosyl core-sulfated diglycosyl diether (17). It has been proposed that members of the genus Halorubrobacterium, which is a junior objective synonym of the genus Halorubrum, contain 1-O- $[\alpha-$ D-mannose- $\left(2^{\prime}-\mathrm{SO}_{4}{ }^{-}\right)-\left(1^{\prime} \rightarrow 4^{\prime}\right)-\alpha$-D-glucose]-2,3-di- $O$-phytanyl-sn-glycerol (9). The major glycolipids of $\arg -1^{\mathrm{T}}$ were TGD-2 and DGD-2 (Fig. 1), which suggested that this strain belongs to the genus Haloarcula. The glycolipids of strain $\arg -2^{\mathrm{T}}$ were similar to DGD-1 and S-DGD as determined by the TLC analysis. On the basis of the results of the glycolipid analysis alone, arg- $2^{\mathrm{T}}$ might be a member of the genus Haloferax. However, arg- $2^{\mathrm{T}}$ contained the phospholipid phosphatidylglycerosulfate, which is absent in the genus Haloferax. Since mutation of the gene(s) encoding a certain enzyme(s) for glycolipid modification may have occurred without affecting the general phenotype, classification on the basis of glycolipids can only be considered circumstantial evidence. Thus, strain $\arg -2^{\mathrm{T}}$ cannot be excluded from the genus Haloarcula by a difference in glycolipids.

Analysis of the 16S rRNAs of 26 halobacterial strains (Fig. 2) revealed seven large clusters, six of which corresponded to the genera Haloarcula, Haloferax, Halobacteria, Halococcus, Halorubrum (Halorubrobacterium), and Halobaculum. The last cluster included three genera (the genera Natronobacterium, Natronococcus, and Natrialba) and some as-yet-unidentified strains. Halobacterium trapanicum NCIMB $767^{\mathrm{T}}$ and NRC $34021^{\mathrm{T}}$ were originally obtained from the same strain, but the phylogenetic positions of these strains were apparently different (Fig. 2). Moreover, the currently available strain NCIMB $767^{\mathrm{T}}$ seems to be a member of the genus Halococcus as determined by cell shape and resistance to low levels of salinity (6a, 31 ). It is necessary to reconsider the validity of Halobacterium trapanicum ATCC $43102^{\mathrm{T}}$, NCIMB $767^{\mathrm{T}}$, and NRC $34021^{\mathrm{T}}$. Strain $\arg -1^{\mathrm{T}}$ was found to fall in the Haloarcula cluster. The species status of $\arg -1^{\mathrm{T}}$ is further supported by the results of DNA-DNA hybridization experiments (Table 1). On the $16 \mathrm{~S}$ rRNA tree (Fig. 2), strain arg- $2^{\mathrm{T}}$ branched off before the main branch of the genus Haloarcula. On the phylogenetic tree constructed by using bacteriorhodopsins, strain arg- $2^{\mathrm{T}}$ similarly branched before other Haloarcula strains (details will be discussed elsewhere). Both of these features suggest that $\arg -2^{\mathrm{T}}$ may be only remotely related to the genus Haloarcula. However, multiple heterologous $16 \mathrm{~S}$ rRNAs have been reported for Haloarcula marismortui and "Haloarcula sinaiiensis" (10, 20) (Fig. 2). This suggests that the 16S rRNA cloned from the strain $\arg -2^{\mathrm{T}}$ genome may be the most remote $16 \mathrm{~S}$ rRNA of the heterologous $16 \mathrm{~S}$ rRNA species in the strain, since at least three 16S rRNA genes were detected in the genome of $\arg -2^{\mathrm{T}}$.

TABLE 1. Levels of DNA-DNA hybridization between the two new strains and various halobacterial strains

\begin{tabular}{|c|c|c|}
\hline \multirow{2}{*}{ Strain } & \multicolumn{2}{|c|}{$\begin{array}{c}\% \text { DNA-DNA } \\
\text { hybridization with: }\end{array}$} \\
\hline & $\arg -1^{\mathrm{T}}$ & $\arg -2^{\mathrm{T}}$ \\
\hline Haloferax volcanii IFO $14742^{\mathrm{T}}$ & 8 & 15 \\
\hline Halobacterium salinarum IFO $14716^{\mathrm{T}}$ & 1 & 2 \\
\hline Halococcus morrhuae JCM $8876^{\mathrm{T}}$ & 2 & 1 \\
\hline Halorubrum saccharovorum IFO $14717^{\mathrm{T}}$ & 7 & 19 \\
\hline Haloarcula vallismortis IFO $14741^{\mathrm{T}}$ & 43 & 26 \\
\hline Haloarcula marismortui JCM $8966^{\mathrm{T}}$ & 56 & 28 \\
\hline Haloarcula hispanica JCM $8911^{\mathrm{T}}$ & 61 & 27 \\
\hline Haloarcula japonica JCM $7785^{\mathrm{T}}$ & 25 & 23 \\
\hline "Haloarcula sinaiiensis" JCM 8862 & 41 & 24 \\
\hline $\arg -1^{\mathrm{T}}\left(=\mathrm{JCM} 9737^{\mathrm{T}}\right)$ & 100 & 27 \\
\hline $\arg -2^{\mathrm{T}}\left(=\mathrm{JCM} 9738^{\mathrm{T}}\right)$ & 17 & 100 \\
\hline
\end{tabular}


Therefore, until all three $16 \mathrm{~S}$ rRNAs are cloned and sequenced, arg- $2^{T}$ cannot be excluded from the genus Haloarcula.

In contrast, when the amino acid sequences of bacteriorhodopsins from various halobacteria were aligned, a specific insertion of six amino acid residues (L-S/P-A-G-A-E) was commonly found only in those sequences obtained from the Haloarcula strains (strains arg- $1^{\mathrm{T}}$ and $\arg -2^{\mathrm{T}}$ and Haloarcula vallismortis). This suggests that the insertion occurred after the divergence of the genera (details will be discussed elsewhere).

In conclusion, chemotaxonomic and genetic data indicate that both $\arg -1^{\mathrm{T}}$ and $\arg -2^{\mathrm{T}}$ are members of the genus Haloarcula in the order Halobacteriales. The distinction of both strains from other validly described species in the genus Haloarcula is supported by the uniqueness of the glycolipids, the low DNA-DNA hybridization values, and the low levels of sequence similarity of the $16 \mathrm{~S}$ rDNAs.

Description of Haloarcula argentinensis sp. nov. Haloarcula argentinensis (ar.gen.ti.nen'sis. M.L. adj. argentinensis pertaining to Argentina). Gram negative. Motile by means of polar flagella. Cells are triangular flat disks in the actively growing stage that are ca. 1.0 by $0.3 \mu \mathrm{m}$. Colonies are about $3 \mathrm{~mm}$ in diameter after 1 week of incubation at $40^{\circ} \mathrm{C}$ on $1.5 \%$ agar plates containing $20 \%$ salt. The colonies are translucent, entire, smooth, orange-red, and mucous on old plates.

Chemoorganotrophic. Growth is strictly aerobic. Growth occurs in the presence of 2.0 to $4.5 \mathrm{M} \mathrm{NaCl}$. Optimum growth occurs in the presence of 2.5 to $3 \mathrm{M} \mathrm{NaCl}$ at $40^{\circ} \mathrm{C}$. The $\mathrm{Mg}^{2+}$ concentration required for growth is $30 \mathrm{mM}$ in solid medium, but the optimum $\mathrm{Mg}^{2+}$ concentration is around $100 \mathrm{mM}$ (in medium containing $2.5 \mathrm{M} \mathrm{NaCl}$ ). Acids are produced from various sugars (sucrose, maltose, glucose, galactose, mannose, ribose, glycerol, and fructose). Resistant to chloramphenicol $(30 \mu \mathrm{g} / \mathrm{ml})$, kanamycin $(30 \mu \mathrm{g} / \mathrm{ml})$, and penicillin $(10 \mathrm{IU} / \mathrm{ml})$. Susceptible to anisomycin $(10 \mu \mathrm{g} / \mathrm{ml})$, novobiocin $(5 \mu \mathrm{g} / \mathrm{ml})$, and pravastatin $(10 \mu \mathrm{g} / \mathrm{ml})$.

The $\mathrm{G}+\mathrm{C}$ content of the DNA is $62 \mathrm{~mol} \%$ (as determined by the thermal denaturation method).

Catalase and oxidase positive. The fructose-bisphosphate aldolase is class I (EDTA insensitive).

Nonsaponifiable ether-linked phosphoglyceride lipids. The major glycolipid is TGD-2.

Contains retinal proteins.

The type strain is strain arg-1 (= JCM 9737).

Description of Haloarcula mukohataei sp. nov. Haloarcula mukohataei (mu.ko.ha.tae'i. M.L. adj. mukohataei, of Yasuo Mukohata, Japanese biochemist and biophysicist).

Gram-negative. Motile by means of polar flagella. Short rods (ca. 2.0 by $0.5 \mu \mathrm{m}$ ) in actively growing cultures and pleiomorphic in stationary cultures. Colonies are about $2 \mathrm{~mm}$ in diameter after 1 week of incubation at $40^{\circ} \mathrm{C}$ on $1.5 \%$ agar plates containing $20 \%$ salt. They are translucent, entire, smooth, and red-orange.

Chemoorganotrophic. Growth is strictly aerobic. Growth occurs in the presence of 2.5 to $4.5 \mathrm{M} \mathrm{NaCl}$; optimum growth occurs in the presence of 3.0 to $3.5 \mathrm{M} \mathrm{NaCl}$ at $40^{\circ} \mathrm{C}$. The minimum $\mathrm{Mg}^{2+}$ concentration required for growth is $3 \mathrm{mM}$ in solid medium, but concentration dependence for growth is not observed at $\mathrm{Mg}^{2+}$ concentrations between 3 and $300 \mathrm{mM}$. Acids are produced from many sugars (sucrose, maltose, glucose, galactose, mannose, ribose, and glycerol). Resistant to chloramphenicol $(30 \mu \mathrm{g} / \mathrm{ml})$, kanamycin $(30 \mu \mathrm{g} / \mathrm{ml})$, and penicillin $(10 \mathrm{IU} / \mathrm{ml})$. Susceptible to anisomycin $(10 \mu \mathrm{g} / \mathrm{ml})$, novobiocin $(5 \mu \mathrm{g} / \mathrm{ml})$, and pravastatin $(10 \mu \mathrm{g} / \mathrm{ml})$.

The $\mathrm{G}+\mathrm{C}$ content of the DNA is $65 \mathrm{~mol} \%$ (as determined by the thermal denaturation method).
Catalase and oxidase positive. The fructose-bisphosphate aldolase is class I (EDTA insensitive).

Nonsaponifiable ether-linked phosphoglyceride lipid. The major glycolipid is unknown.

Contains retinal protein.

The type strain is strain arg-2 (= JCM 9738).

\section{ACKNOWLEDGMENTS}

We thank Yasuo Mukohata, and one of the strains described in this paper was named after him for his contribution to the study of bioenergetics in halobacteria.

The strains characterized in this study were collected in Argentine salt flats in 1991 by a survey team that included Yasuo Mukohata, Naoki Kamo (Hokkaido University), Tetsuya Konishi (Niigata Pharmaceutical College), Yasuo Sugiyama (Nagoya University), Paul Lewis, and Daniel Tuesca (University of Rosario) and was supported by a grant-in-aid for international scientific research for the survey of extreme halophiles in Argentina from the Ministry of Education, Science and Culture in Japan.

\section{REFERENCES}

1. Dhar, N. M., and W. Altekar. 1986. Distribution of class I and class II fructose bisphosphate aldolases in halophilic archaebacteria. FEMS Microbiol. Lett. 35:177-181.

2. Dussault, H. P. 1955. An improved technique for staining red halophilic bacteria. J. Bacteriol, 70:484-485.

3. Felsenstein, J. 1985. Confidence limits on phylogenies: an approach using the bootstrap. Evolution 39:783-791.

4. Grant, W. D., and H. Larsen. 1989. Extremely halophilic archaebacteria, order Halobacteriales ord. nov., p. 2216-2233. In J. T. Staley, M. P. Bryant, N. Pfennig, and J. G. Holt (ed.), Bergey's manual of systematic bacteriology, vol. 3. Williams \& Wilkins, Baltimore, Md.

5. Gupta, R., J. M. Lanter, and C. R. Woese. 1983. Sequence of the $16 \mathrm{~S}$ ribosomal RNA from Halobacterium volcanii, an archaebacterium. Science 221:656-659.

6. Hui, I., and P. P. Dennis. 1985. Characterization of the ribosomal RNA gene clusters in Halobacterium cutirubrum. J. Biol. Chem. 260:899-906.

6a.Ihara, K. Unpublished data.

7. Ihara, K., and Y. Mukohata. 1991. The ATP synthase of Halobacterium salinarium (halobium) is an archaebacterial type as revealed from the amino acid sequences of its two major subunits. Arch. Biochem. Biophys. 286:111116.

8. Johnson, J. L. 1989. Bacterial classification. III. Nucleic acids in bacterial classification, p. 1608-1614. In J. T. Staley, M. P. Bryant, N. Pfennig, and J. G. Holt (ed.), Bergey's manual of systematic bacteriology, vol. 3. Williams \& Wilkins, Baltimore, Md.

9. Kamekura, M., and M. L. Dyall-Smith. 1995. Taxonomy of the family Halobacteriaceae and the description of two new genera, Halorubrobacterium and Natrialba. J. Gen. Appl. Microbiol. 41:333-350.

10. Kamekura, M., and Y. Seno. 1992. Nucleotide sequences of 16S rRNA encoding genes from halophilic archaea Halococcus morrhuae NRC16008 and Haloferax mediterranei ATCC33500. Nucleic Acids Res. 20:3517.

11. Kamekura, M., and Y. Seno. 1993. Partial sequence of the gene for a serine protease from a halophilic archaeum, Haloferax mediterranei $\mathrm{R} 4$, and nucleotide sequences of $16 \mathrm{~S}$ rRNA encoding genes from several halophilic archaea. Experientia 49:503-513.

12. Kates, M., and S. C. Kushwaha. 1995. Isoprenoids and polar lipids of extreme halophiles, p. 35-54. In S. DasSarma and E. M. Fleishmann (ed.), Archaea: a laboratory manual. Halophiles. Cold Spring Harbor Laboratory Press, Cold Spring Harbor, N.Y.

13. Kitajima, T., J.-I. Hirayama, K. Ihara, Y. Sugiyama, N. Kamo, and Y. Mukohata. 1996. Novel bacterial rhodopsins from Haloarcula vallismortis. Biochem. Biophys. Res. Commun. 220:341-345.

14. Leffers, H., and R. A. Garrett. 1984. The nucleotide sequence of the $16 \mathrm{~S}$ ribosomal RNA gene of the archaebacterium Halococcus morrhuae. EMBO J. 3:1613-1619.

15. Lodwick, D., H. N. M. Ross, J. E. Harris, J. W. Almond, and W. D. Grant. 1986. dam Methylation in the archaebacteria. J. Gen. Microbiol. 132:30553059 .

16. Mankin, A. S., V. K. Kagramanova, N. L. Teterina, P. M. Rubtsov, E. N Belova, A. M. Kopylov, L. A. Baratova, and A. A. Bogdanov. 1985. The nucleotide sequence of the gene coding for the 16S rRNA from the archaebacterium Halobacterium halobium. Gene 37:181-189.

17. McGenity, T. J., and W. D. Grant. 1995. Transfer of Halobacterium saccharovorum, Halobacterium sodomense. Halobacterium trapanicum NRC34021 and Halobacterium lacusprofundi to the genus Halorubrum gen. nov., as Halorubrum saccharovorum comb. nov., Halorubrum sodomense comb. nov. Halorubrum trapanicum comb. nov., and Halonibrum lacusprofundi comb. 
nov. Syst. Appl. Microbiol. 18:237-243.

18. Minninkin, D. E., M. D. Collins, and M. Goodfellow. 1977. Fatty acid and polar lipid composition in the classification of Cellulomonas, Oerskovia and related taxa. J. Appl. Bacteriol. 47:87-96.

19. Mukohata, Y. 1994. Comparative studies on ion pumps of the bacterial rhodopsin family. Biophys. Chem. 50:191-201.

20. Mylvaganam, S., and P. P. Dennis. 1992. Sequence heterogeneity between the two genes encoding 16S rRNA from the halophilic archaebacterium Haloarcula marismortui. Genetics 130:399-410.

21. Oren, A., P. Gurevich, R. T. Gemmell, and A. Teske. 1995. Halobaculum gomorrense gen. nov., sp. nov., a novel extremely halophilic archaeon from the Dead Sea. Int. J. Syst. Bacteriol. 45:747-754.

22. Rodriguez-Valera, F., F. Ruiz-Berraquero, and A. Ramos-Cormenzana. 1980. Isolation of extremely halophilic bacteria able to grow in defined inorganic media with single carbon sources. J. Gen. Microbiol. 119:535-538.

23. Ross, H. N. M., M. D. Collins, B. J. Tindall, and W. D. Grant. 1981. A rapid procedure for the detection of archaebacterial lipids in halophilic bacteria. J. Gen. Microbiol. 123:75-80.

24. Saiki, G. K., D. H. Gelfand, S. Stoffel, S. Scharf, R. Higuchi, G. T. Horn, K. B. Mullis, and H. A. Erlich. 1988. Primer-directed enzymatic amplification of DNA with thermostable DNA polymerase. Science 239:487-491.

25. Saitou, N., and M. Nei. 1987. The neighbor-joining method: a new method for reconstructing phylogenetic trees. Mol. Biol. Evol. 4:406-425.

26. Sambrook, J., E. F. Fritsch, and T. Maniatis. 1989. Molecular cloning: a laboratory manual, 2nd ed. Cold Spring Harbor Laboratory Press, Cold Spring Harbor, N.Y.

27. Smibert, R. M., and N. R. Krieg. 1981. General characterization, p. 409-443. In P. Gerhardt, R. G. E. Murray, R. N. Costilow, E. W. Nester, W. A. Wood,
N. R. Krieg, and G. B. Phillips (ed.), Manual of methods for general bacteriology. American Society for Microbiology, Washington, D.C.

28. Sugiyama, Y., N. Yamada, and Y. Mukohata. 1994. The light-driven proton pump, cruxrhodopsin-2 in Haloarcula sp. $\arg -2\left(\mathrm{bR}^{+}, \mathrm{hR}^{-}\right)$, and its coupled ATP formation. Biochim. Biophys. Acta 1188:287-292.

29. Tateno, M., K. Ihara, and Y. Mukohata. 1994. The no:el ion pump rhodopsins from Haloarcula form a family independent from both the bacteriorhodopsin and archaerhodopsin families/tribes. Arch. Biochem. Biophys. 315: $127-132$

30. Thompson, J. D., D. G. Higgins, and T. J. Gibson. 1994. CLUSTAL W: improving the sensitivity of progressive multiple sequence alignment through sequence weighting, position-specific gap penalties and weight matrix choice. Nucleic Acids Res. 22:4673-4680.

31. Tindall, B. J. 1992. The family Halobacteriaceae, p. 768-808. In A. Balows, H. G. Truper, M. Dworkin, W. Harder, and K.-H. Schleifer (ed.), The prokaryotes, 2nd ed., vol. I. Springer-Verlag, New York, N.Y.

32. Tindall, B. J., H. N. M. Ross, and W. D. Grant. 1984. Natronobacterium gen. nov. and Natronococcus gen. nov., two new genera of haloalkaliphilic archaebacteria. Syst. Appl. Microbiol. 5:41-57.

33. Torreblanca, M., F. Rodriguez-Valera, G. Juez, A. Ventosa, M. Kamekura, and M. Kates. 1986. Classification of non-alkaliphilic halobacteria based on numerical taxonomy and polar lipid composition, and description of Haloarcula gen. nov. and Haloferax gen. nov. Syst. Appl. Microbiol. 8:89-99.

34. Ventosa, A., and A. Oren. 1996. Halobacterium salinarum nom. corrig., a name to replace Halobacterium salinarium (Elazari-Volcani) and to include Halobacterium halobium and Halobacterium cutirubrum. Int. J. Syst. Bacteriol. 46:347. 